\title{
Pelatihan Pelaporan Keuangan Guna Persiapan Rapat Anggota Tahunan (RAT) Tutup Buku Tahunan Di Koperasi Bromo Semeru Center Kecamatan Tumpang
}

\author{
Mulyaningtyas ${ }^{1}$, Mariana Puspa Dewi ${ }^{2}$, Fadilla Cahyaningtyas ${ }^{3^{*}}$, Justita Dura ${ }^{4}$, \\ Rifki Hanif ${ }^{5}$ \\ ${ }^{1-5}$ Institut Teknologi dan Bisnis Asia Malang \\ ${ }^{*}$ Corresponding author \\ E-mail: fadillacahyaningtyas@asia.ac.id
}

Article History:

Received: 27-10-2020

Revised: 21-11-2021

Accepted: 8-7-2021
Keywords:

\begin{abstract}
Koperasi merupakan penggerak ekonomi kerakyatan di Indonesia. Namun demikian sebagian besar koperasi belum aktif dalam melakukan kegiatan Rapat Anggota Tahunan (RAT) setiap tahunnya. RAT dilaksanakan sebagai bentuk pertanggungjawaban pengurus kepada anggota. Salah satu pembahasan RAT adalah penyajian laporan keuangan. Namun pada kenyataanya masih banyak pengurus koperasi di Indonesia belum memiliki pemahaman dan keterampilan mengenai penyusunan laporan keuangan. $\mathrm{Hal}$ inilah yang mendorong dan memotivasi tim untuk melakukan pelatihan pelaporan keuangan guna persiapan RAT. Koperasi melakukan pelatihan dan pendampingan di Koperasi Bromo Semeru Center Kecamatan Tumpang. Koperasi ini dipilih, karena berdasarkan penelusuran tim, koperasi ini pernah kena sanksi dinonaktifan, sebagai akibat tidak melaksanakan RAT. Salah satu permasalahan yang dihadapi oleh pengurus adalah kesulitan dalam penyusunan laporan keuangan. Oleh karena itu, Tim melakukan pelatihan dan pendampingan dalam Menyusun laporan keuangan koperasi. Perbaikan yang bisa diperoleh adalah peningkatan pemahaman tentang pentingnya laporan keuangan dan peningkatan keterampilan pengurus koperasi dalam bidang akuntansi. Dari pendampingan ini, pengurus koperasi dapat mengimplementasikan pencatatan dan penyusunan laporan keuangan sederhana, melalui Microsoft excel.

Koperasi, Pelaporan Keuangan, RAT, Pelatihan dan Pendampingan
\end{abstract}

\section{Pendahuluan}

Koperasi merupakan salah satu badan usaha yang terdapat di Indonesia, di mana koperasi berperan sebagai penggerak ekonomi kerakyatan yang berorientasi untuk menumbuhkan dan mengembangkan partisipasi masyarakat (Hamdani \& Aulia, 2018) dalam mewujudkan ekonomi yang mempunyai ciri-ciri demokratis, 
kebersamaan, kekeluargaan, dan keterbukaan (Winarko, 2011). Koperasi lebih memfokuskan untuk memenuhi kebutuhan lokal para anggotanya, sehingga koperasi memberikan peluang bagi masyarakat untuk membantu dirinya sendiri (Agustia \& Palupi, 2016). Oleh karena itu, koperasi digunakan sebagai wadah usaha bersama untuk memenuhi aspirasi dan kebutuhan ekonomi para anggota koperasi dan bagi masyarakat (Suwetty, 2017). Hal ini sesuai dengan nilai-nilai yang tertuang Pasal 5 UU RI Nomor 172012 tentang perkoperasian, di mana kegiatan koperasi didasari oleh nilai-nilai, yaitu kekeluargaan; menolong diri sendiri; bertanggung jawab; demokrasi; persamaan; berkeadilan; dan kemandirian (UU RI Nomor 17, 2012).

Di Indonesia, eksistensi koperasi memang merupakan suatu fenomena tersendiri, di mana perannya tidak bisa digantikan oleh lembaga keuangan lainnya ((Hidayat et al., 2016). Lebih lanjut, Beberapa tahun terakhir ini perkembangan kelembagaan koperasi di Indonesia cukup mengalami pasang surut. Perkembangan pembangunan koperasi dapat ditunjukkan melalui peningkatan jumlah koperasi dan bertambahnya jumlah anggota yang terdaftar. Berdasarkan data BPS (2019), Jawa Timur memiliki koperasi aktif terbanyak dibandingkan dengan ke-33 provinsi lainnya selama 5 tahun terakhir. Namun banyaknya koperasi yang masih aktif ini, tidak diikuti dengan keaktifan koperasi dalam melaksanakan Rapat Anggota Tahunan (lihat di tabel 1). Hal inilah yang menjadi alasan tim kami berinisiatif melakukan pengabdian pada koperasi di Jawa Timur.

Tabel 1. Data Koperasi Jawa Timur (2015-2019)

\begin{tabular}{ccccc}
\hline No & Tahun & Koperasi Aktif (Unit) & RAT (Unit) & Jumlah Anggota (Orang) \\
\hline 1 & 2015 & 27.472 & 12.343 & 7.622 .390 \\
2 & 2016 & 27.683 & 4.452 & 1.110 .296 \\
3 & 2017 & 27.683 & 8.234 & 2.762 .151 \\
4 & 2018 & 24.024 & 11.776 & 3.313 .030 \\
5 & 2019 & 21.757 & 13.174 & 3.620 .213 \\
\hline
\end{tabular}

Sumber: (Depkop, 2019)

Berdasarkan tabel 1 di atas, jika dilihat dari unit kelembagaannya, dapat dilihat bahwa di tahun 2016 dan 2017, kelembagaan koperasi meningkat sebesar 0,7\% dibanding tahun 2015. Namun, ditahun 2018 dan 2019 secara berturut-turut kelembagaan koperasi mengalami penurunan yang cukup besar yaitu $2,3 \%$ dan $9.4 \%$. Naik turunnya kelembagaan koperasi juga dapat dilihat dari jumlah anggota koperasi per tahunnya. Dengan mengamati tabel di atas, dapat dilihat bahwa pada tahun 2016, jumlah keanggotan koperasi mengalami penurunan yang sangat besar dibanding tahun 2015, yaitu sebesar $85,43 \%$. Namun, sebaliknya pada tahun 2017,2018 , dan 2019 secara berturut-turut keanggotaan koperasi mengalami peningkatan secara perlahan, yaitu 59,8\%; 16,63\%; dan 8,49\%. Jika dicermati lebih dalam, dapat dilihat bahwa terdapat perbedaan perkembangan unit koperasi dan jumlah anggota per tahunnya. Bedasarkan tabel, dapat dilihat bahwa jumlah unit koperasi yang aktif 
mengalami penurunan setiap tahunnya, sedangkan jika dilihat dari jumlah anggota, walaupun selama dua tahun berturut-turut mengalami penurunan, tetapi pada dua tahun berikutnya mengalami peningkatan berturut-turut. Berdasarkan hal ini, dapat disimpulkan bahwa peningkatan ataupun penurunan jumlah anggota tidak menjamin peningkatan koperasi aktif di Jawa Timur.

Lebih lanjut, berdasarkan tabel di atas juga dapat dilihat keaktifan koperasi dalam melakukakan Rapat Anggota Tahunan (RAT). Pada tahun 2015, dapat dilihat koperasi yang melakukan RAT sebesar $45 \%$ dari 27.472 koperasi aktif. Sedangkan, pada tahun 2016 dan 2017 secara berturut-turut keaktifan koperasi melakukan RAT penurunan tajam walaupun jumlah koperasi aktif sama, di mana koperasi yang melakukan RAT hanya sebesar $16,08 \%$ dan $29,74 \%$ dari koperasi yang aktif. Kemudian, pada tahun 2018 dan 2019 keaktifan koperasi yang melaksanakan RAT mengalami peningkatan. Selama dua tahun berturut-turut tersebut, koperasi yang sudah melaksanakan RAT yaitu sebesar 49\% dan 60,55\%. Berdasarkan data tersebut, dapat dilihat bahwa prosentase keaktifan koperasi dalam melaksanakan RAT masih sangat kecil, padahal sebenarnya kegiatan RAT adalah kegiatan yang wajib dilakukan di Indonesia.

RAT dilaksanakan sebagai wujud dari kinerja koperasi yang baik karena mampu mempertanggungjawabkan segala akitivitas usaha kepada anggota (Suwetty, 2017). Selain itu, pada RAT juga akan membahas mengenai penyusunan rencana anggaran pendapatan dan belanja koperasi untuk tahun buku selanjutnya (Hamdani \& Aulia, 2018; Zulkifli \& Rachim, 2019). Kewajiban pelaksanaan RAT Koperasi juga tertuang dalam Permen no. 19 pasal 4 ayat (2) yang menyatakan bahwa Rapat Anggota wajib dilaksanakan koperasi paling sedikit satu (1) kali dalam satu tahun buku (Permen No. 19 Tentang Penyelenggaran Rapat Anggota Koperasi, 2015). Dan bagi Koperasi yang tidak melaksanakan RAT akan mendapat sanksi seperti yang tertuang pada UU. No 17 pasal 120 yang menyatakan bahwa Menteri dapat menjatuhkan sanksi administratif terhadap koperasi yang tidak melaksanakan RAT tahunan setelah 2 (dua) tahun buku terlampaui (UU RI Nomor 17, 2012). Lebih rinci, sanksi administratif juga tertuang dalam Permen no. 19 pasal 20 ayat (3), yaitu berupa: (a) Bagi koperasi yang terlambat melakukan RAT dalam satu tahun akan diberikan surat peringatan tertulis oleh pejabat berwenang; (b) Bagi koperasi yang terlambat melaksanakan RAT 2 kali berturut-turut diberi surat peringatan tertulis dan ditembuskan kepada Deputi Bidang Pengawasan dan pihak terkait lainnya; (c) Bagi koperasi yang tidak melaksanakan RAT akan diberi surat teguran atau peringgatan tertulis; (d) bagi koperasi yang tidak melaksanakan RAT minimal dua kali atau lebih secara berturut-turut akan diberi surat Surat peringatan tertulis dan surat rencana pembubaran oleh pejabar berwenang (Permen No. 19 Tentang Penyelenggaran Rapat Anggota Koperasi, 2015). 
Oleh karena itu, untuk menghindari sanksi-sanksi administratif seharusnya koperasi melaksanakan RAT sebanyak satu kali dalam setahun. Namun, Kenyataannya masih banyak koperasi aktif tidak melaksanakan rapat anggota tahunan. Bahkan, kami menemukan salah satu koperasi yang terletak di Kota Malang Jawa timur, telah mendapatkan sanksi administrative karena tidak melakukan RAT lebih dari satu kali. Adapun sanksi administrasinya yaitu, di non aktifkannya koperasi tersebut. Koperasi tersebut adalah Koperasi Bromo Semeru Center Kecamatan Tumpang.

Atas dasar salah satu kasu tersebut dapat dilihat, masih banyakya ketidakaktifan koperasi dalam melakasanakan rapat aggota disebabkan oleh beberapa permasalahan, salah satunya adalah masih buruknya manajemen koperasi. Selanjutnya, Buruknya manajemen ini dapat banyak memberikan dampak bagi koperasi, antara lain sumber daya manusia yang tidak terpelihara, alur koordinasi yang berantakan, kesalahan administrasi bahkan peluang terjadinya penyimpangan laporan keuangan (Zulkifli \& Rachim, 2019), padahal laporan keuangan diperlukan sebagai pertanggungjawaban pengurus dalam RAT (Hamdani \& Aulia, 2018).

Laporan keuangan koperasi yang disampaikan di RAT berisi informasi mengenai seluruh aktivitas keuangan dan posisi sumber daya yang dimiliki oleh kopeasi selama satu periode (Aulia \& Hamdani, 2018). Namun, penyusunan laporan keuangan juga menjadi salah satu permasalahan Koperasi di Indonesia. Hal ini disebabkan karena masih minimnya kompetensi dari penyusunan laporan keuangan koperasi (Purwanti \& Kurniawan, 2013). Banyak koperasi yang belum menerapkan SAK ETAP, padahal dalam penyusunan laporan keuangan koperasi sudah seharusnya disusun berdasarkan SAK ETAP, sehingga informasi yang disampaikan tidak menyesatkan bagi pengguna laporan keuangan (Aulia \& Hamdani, 2018; Purwanti \& Kurniawan, 2013). Oleh karena itu, pemahaman atas laporan keuangan akan mempermudah dan mempercepat pelaksanaan RAT (Hamdani \& Aulia, 2018).

Mengingat masih minimnya pemahaman sumber daya manusia dalam penyusunan laporan keuangan di koperasi Indonesia, sedangkan laporan keuangan menjadi bagian yang wajib disampaikan dalam RAT setiap tahunnya. Oleh karena itu, kami tertarik melaksanakan pengabdian masyarakat dengan salah satu mitra kami, yaitu Koperasi Bromo Semeru center Kecamatan tumpang dengan memberikan pelatihan dalam tema "Pelatihan Pelaporan Keuangan Guna Persiapan Rapat Anggota Tahunan (RAT) Tutup Buku Tahun 2019 di Koperasi Bromo Semeru Center Kecamatan Tumpang". Setelah pengabdian masyarakat ini, kami mengharapkan pelaksanaan RAT tutup buku tahun 2019 di Koperasi Bromo Semeru Center Kecamatan Tumpang dapat berjalan baik, mengingat koperasi ini pernah dinonaktifkan. 


\section{Metode}

Pelaksanaan pengabdian kepada masyarakat ini diarahakan agar mitra koperasi dapat memiliki kemampuan yang lebih baik dalam penyusunan laporan keuangan untuk persiapan RAT tutup buku tahun 2019. Kegiatan ini akan di fokuskan pada pengenalan dan pemahaman atas laporan keuangan, serta cara penyusunan laporan keuangan. Adapun alur kegiatan ini ditunjukkan pada Gambar 1.

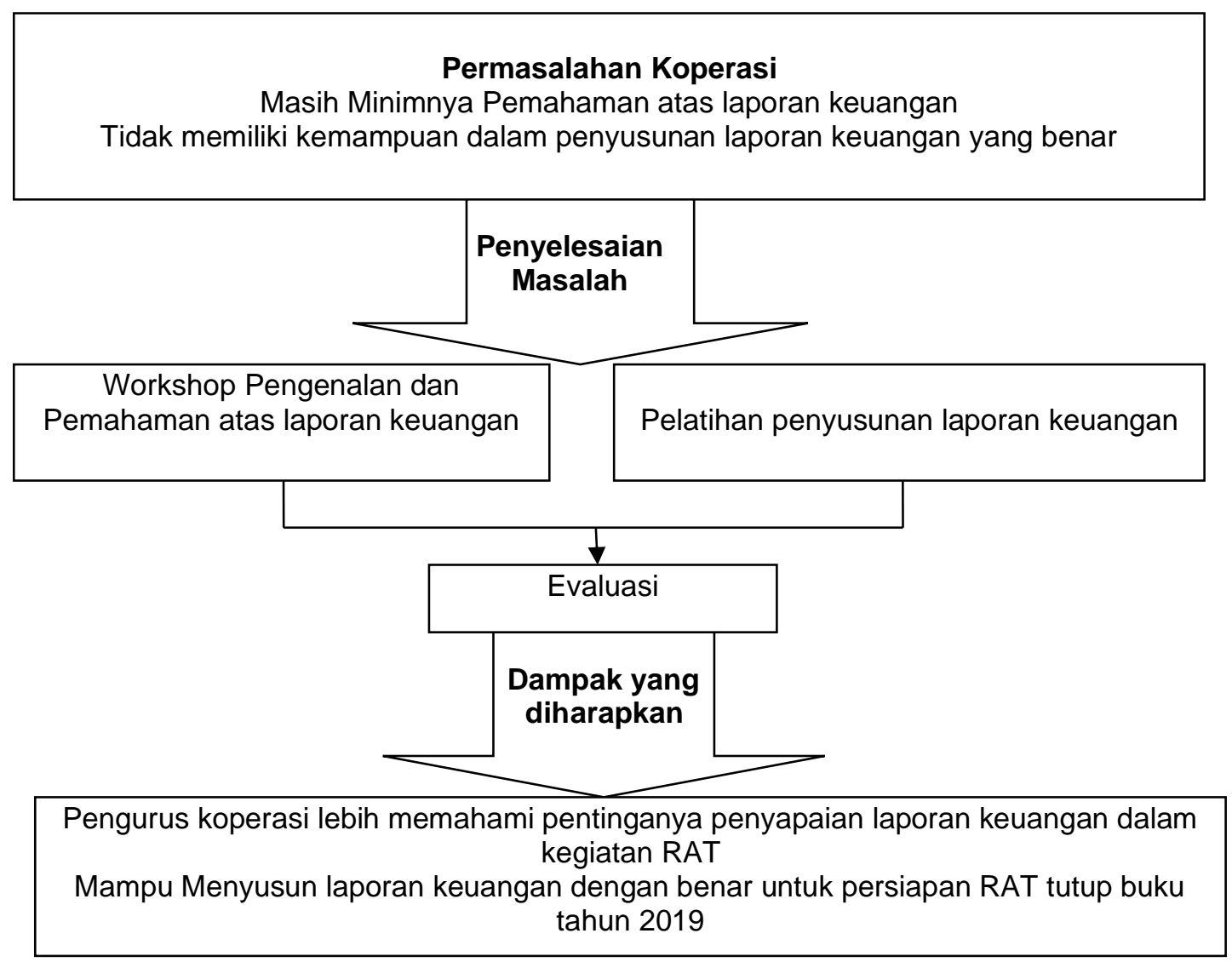

Gambar 1. Alur Kegiatan Pengabdian Kepada Masyarakat

Pada sesi pertama, tim akan memberikan workshop pemahaman atas laporan keuangan. Melalui workshop ini, tim akan memberikan pemahaman pentingnya pencatatan keuangan dan penyusunan laporan keuangan yang benar dan rapi, serta pentingnya penyampaian laporan keuangan yang tepat dalam RAT. Karena mengingat masih lemahnya pemahaman pengurus koperasi dalam memahami standar-standar akuntansi yang berlaku, maka dalam workshop ini, tim juga akan menjelaskan standar-standar akuntansi yang perlu diketahui dan diimplementasikan oleh pengurus koperasi.

Setelah memahami lebih dalam mengenai laporan keuangan, kegiatan pengabdian ini akan dilanjutkan pada sesi kedua, yaitu pelatihan penyusunan laporan keuangan. Adapun materi-materi yang akan tim berikan, antara lain (1) Sistem Informasi Akuntansi. Pada materi ini tim akan menjelaskan alur-alur pencatatan, yang dimulai dari pengumpulan bukti transaksi hingga penyusunan laporan keuangan; (2) 
Pemberian contoh studi kasus, di mana tim akan memberikan contoh2 pencatatanpencatatan hingga penyusunan laporan keuangan sederhana koperasi.

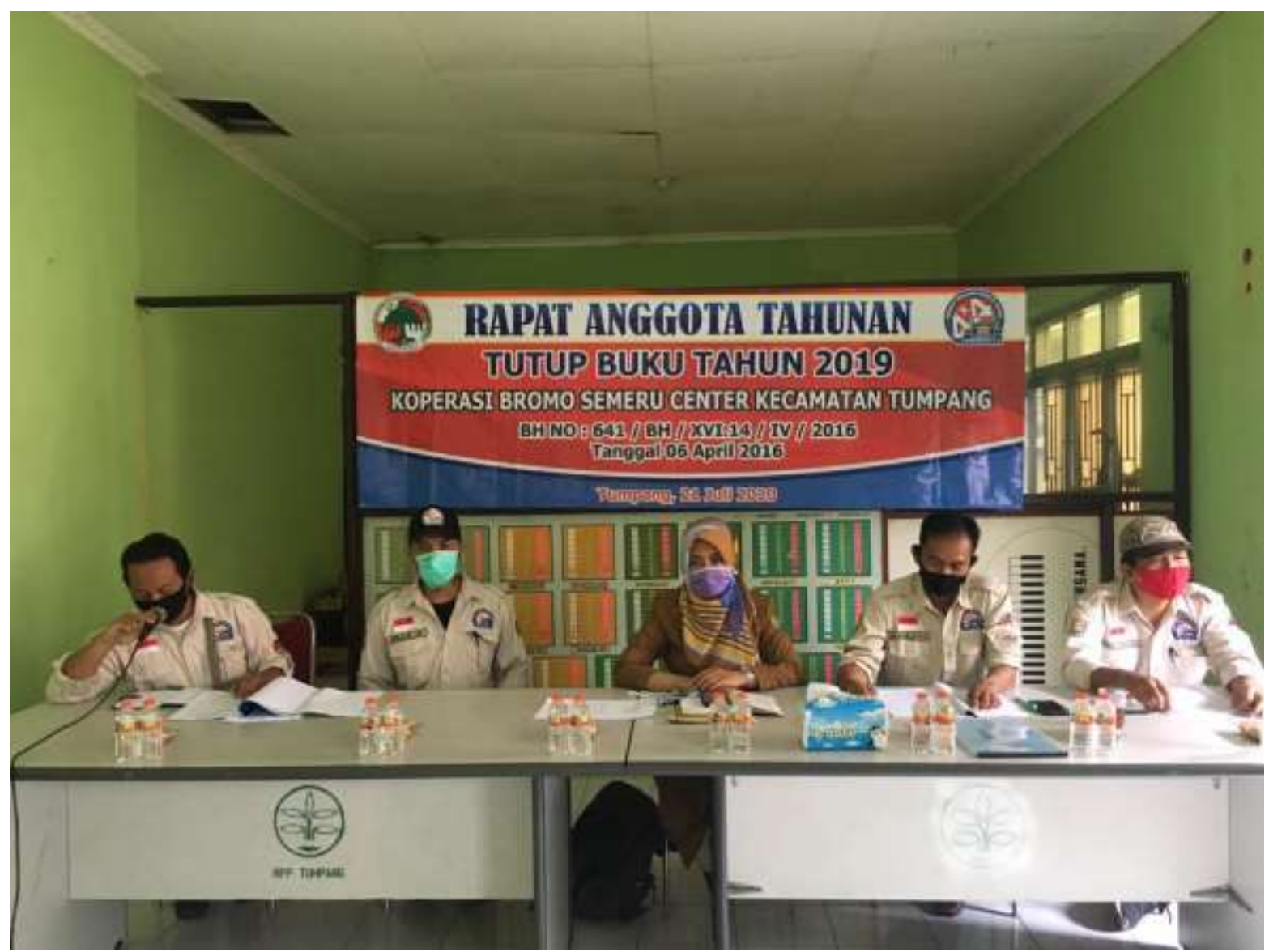

Gambar 2. Pendampingan Tim Pengabdian kepada Pengurus dan Anggota Koperasi

Pada sesi terakhir, tim akan melanjutkan dengan evaluasi. Evaluasi ini dilakukan bersama dengan peserta kegiatan pengabdian ini. Evaluasi dilakukan dalam beberapa bentuk. Pertama, Evaluasi dilakukan terhadap tingkat pemahaman materi yang telah diberikan pada kegiatan ini dengan melakukan tanya jawab. Kedua, Evaluasi dilakukan terhadap cara pencatatan dan penyusunan laporan keuangan koperasi selama ini. Tim membantu pendampingan dalam melakukan pencatatan dan penyusunan laporan keuangan, di mana pada bagian ini, tim dan pengurus koperasi terkait melakukan diskusi lanjutan dengan tim terkait transaksi selama tahun 2019, hingga pada penyusunan laporan keuangan tutup buku tahun 2019. 


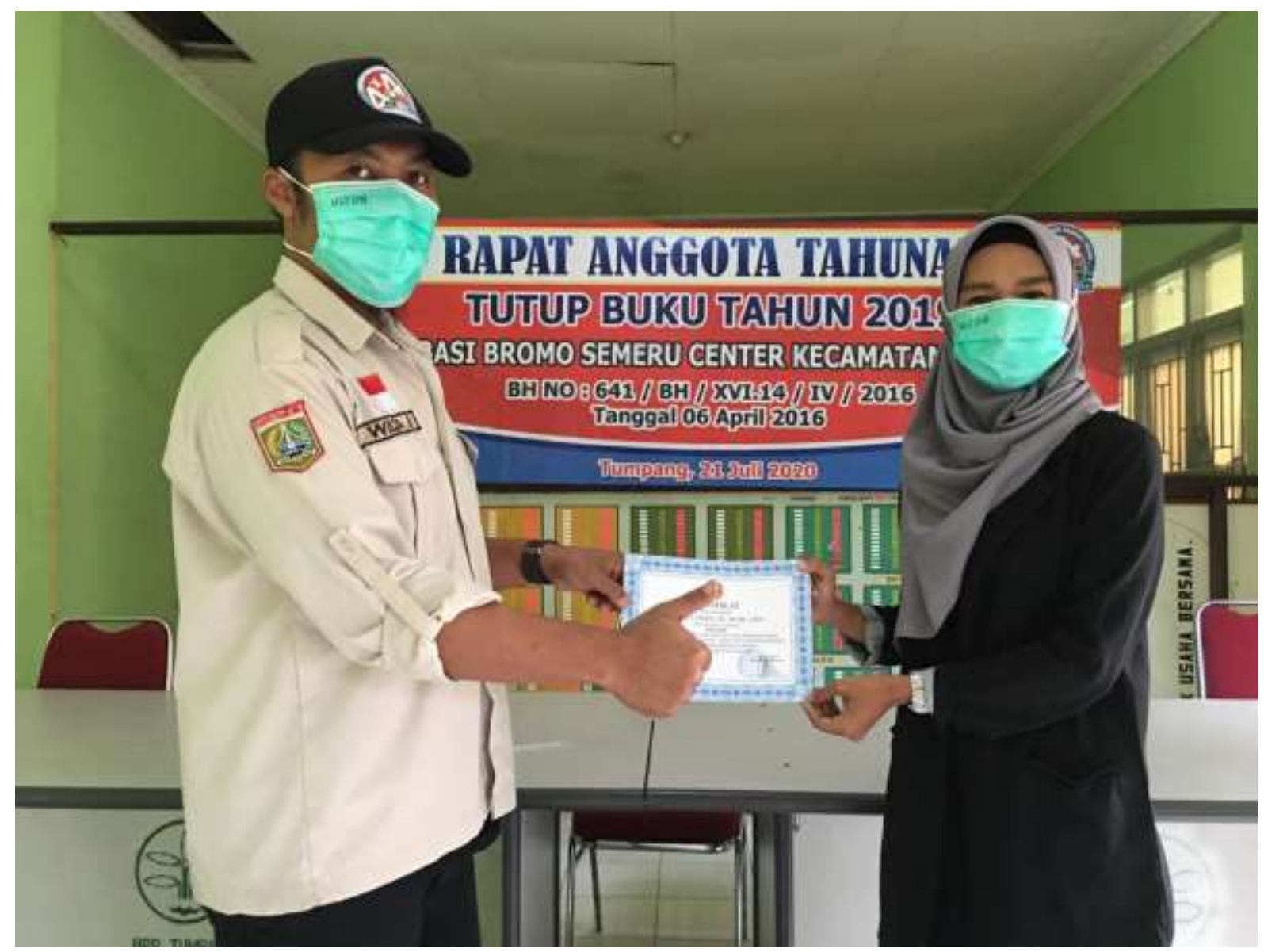

Gambar 3. Pemberian Sertifikat Kepada Perwakilan Tim Pengabdian

\section{Hasil}

Pada tahap awal tim melakukan observasi koperasi Bromo Semeru Center Kecamatan Tumpang. Koperasi ini merupakan jenis koperasi simpan pinjam, di mana kegiatan usahanya hanya menghimpun dana dan menyalurkannya melalui kegiatan usaha simpan pinjam (Government Regulation No. 20/2008, 2008). Pada observasi awal, tim bertemu dan melakukan wawancara dengan beberapa pengurus koperasi. Melalui wawancara ini, tim melakukan pengenalan lebih dalam mengenai permasalahan yang dihadapi oleh pengurus koperasi. Berdasarkan hasil wawancara ini, tim menemukan permasalahan serius yang dihadapi oleh koperasi. Permasalahan tersebut adalah koperasi di non-aktifkan. Dinas Koperasi dan UMKM memberikan syarat jika ingin mengaktifkan kembali Koperasi tersebut harus melakukan Rapat Tahunan Anggota. Untuk mencari penyebab permasalahan ini, tim pengabdian kami mencoba menelusuri lebih dalam. Dan berdasarkan penelusuran lebih dalam, tim menyimpulkan bahwa terdapat dua penyebab utama permasalahan koperasi, yaitu minimnya pemahaman laporan keuangan dan kesulitan pengurus koperasi dalam Menyusun laporan keuangan. Kedua penyebab ini yang menghambat koperasi melakukan kegiatan RAT. 
Untuk mengatasi permasalahan pertama, tim sepakat untuk menyusul modul pelatihan, di mana modul ini digunakan sebagai bahan pelatihan dan pendampingan. Selain digunakan untuk pelatihan dan pendampingan, modul ini dapat dijadikan pegangan pengurus dalam menjalankan koperasi selanjutnya. Adapun modul yang dihasilkan pada kegiatan pengabdian ini yaitu (1) Pemahaman secara Umum mengenai Laporan Keuangan. Pada bagian ini kami menjelaskan mengenai pengertian laporan keuangan, jenis-jenis laporan keuangan yang dapat digunakan oleh koperasi. Untuk mempermudah pemahaman pengurus mengenai apa itu laporan keuangan, kami menggunakan beberapa referensi yang mudah dipahami. Secara garis besar, kami menjelaskan laporan keuangan merupakan suatu proses pencatatan, dimana berisikan ringkasan transaksi-transaksi yang terjadi selama tahun. Laporan koperasi menyajikan informasi yang menyangkut kondisi, kinerja, dan perubahan posisi keuangan, dimana dapat digunakan dalam pengambilan keputusan. Lebih lanjut, dengan mendasar pada SAK ETAP, maka badan koperasi dapat menyajikan laporan keuangan, yang terdiri dari neraca, laporan laba rugi, laporan perubahan modal, laporan arus kas, dan catatan atas laporan keuangan. (2) Standar akuntansi keuangan yang dapat digunakan oleh koperasi. Pada bagian modul ini, kami menjelaskan standar akuntansi keuangan koperasi yaitu SAK ETAP. Hal ini sesuai dengan surat edaran Deputi Kelembagaan dan UKM RI nomor: 200/SE/Dept.1/XII/2011 sehubungan dengan pemberlakuan IFRS. Surat edaran ini menyatakan bahwa entitas koperasi dalam penyusunan dan penyajian laporan keuangan mengacu pada SAK ETAP (Entintas Tanpa Akuntabilitas Publik). Agar pengurus koperasi dapat mempelajari peraturan ini, maka tim kami sepakat untuk memberikan satu eksemplar SAK ETAP. Selain itu, SAK ETAP ini akan kami gunakan sebagai dasar pendampingan saat praktik penyusunan laporan keuangan koperasi mitra kami. (3) Pentingnya pelaporan koperasi dalam kegiatan RAT. Pada bagian ini kami juga menjelaskan pentingnya laporan keuangan untuk disampaikan pada kegiatan RAT. Laporan keuangan disampaikan pada seluruh anggota koperasi bertujuan untuk memberikan pertanggungjawaban kepada anggota koperasi mengenai penggunaan ataupun pemasukan dana. Dengan adanya pelaporan keuangan ini, diharapakan dapat meningkatkan kepercayaan anggota kepada pengurus koperasi. (4) Contoh-contoh laporan keuangan Koperasi. Selain materi yang kami jelaskan, untuk meningkatkan pemahaman penyusunan laporan keuangan oleh pengurus, kami juga memberikan contoh system akuntansi sederhana pada koperasi. Contoh-contoh ini, kami ambil dari beberapa referensi yang ada.

Selanjutnya, untuk mengatasi permasalahan kedua, maka pada kegiatan pengabdian ini, tim kami sepakat untuk melakukan pendampingan dalam praktik penyusunan laporan keuangan oleh pengurus koperasi. Sebelumnya, kami meminta agar pengurus koperasi menyiapkan bukti-bukti transaksi selama tahun 2019. Kami melakukan pendampingi, dimulai dari pengumpulan bukti transaksi, dan membuat nama dan nomor akun yang dibutuhkan oleh koperasi. Akun yang dibutuhkan koperasi, seperti pendapatan jasa, pendapatan bunga, kas, modal awal, seluruh akun 
terkait aset yang dimiliki serta penyusutan, dan sebagainya. Selanjutnya, dari bukti transaksi tersebut, kami mendampingi pengurus untuk membuat template yang dibutuhkan melalui Microsoft excel, seperti jurnal, buku besar, dan neraca lajur. Setelah semua tersedia, kami mendampingi pengurus koperasi untuk belajar membuat jurnal yang diperlukan, lalu diteruskan pencatatan pada buku besar, neraca lajur, hingga penyusunan laporan keuangan sederhana. Selain membuat kartu pinjaman anggota, kami juga menyarankan koperasi untuk membuat buku besar pembantu melalui Microsoft excel, untuk mengetahui posisi piutang masing-masing anggota. Buku besar pembantu ini nantinya akan diberi nama masing-masing anggota koperasi, sehingga akan memudahkan pengurus koperasi untuk melakukan kontrol.

Setelah melakukan pendampingan, tahap terakhir pada kegiatan pengabdian ini adalah evaluasi kegiatan. Evaluasi kami lakukan bersama dengan pengurus koperasi terlibat. Adapun hasil dari evaluasi kami, antara lain (1) Karena sumber daya manusia terbatas dan kurang berkompeten dalam bidang keuangan, pengurus koperasi membutuhkan waktu yang lama untuk mempelajari cara Menyusun laporan keuangan; (2) Pendampingan penyusunan laporan keuangan masih dilakukan secara manual melalui Microsoft excel karena kurangnya sumber daya yang memadai; (3) Pengurus koperasi belum memiliki kemampuan yang baik dalam mengoperasika Microsoft excel, sehingga membutuhkan waktu yang lama untuk membuat pencatatan dan penyusunan laporan keuangan. Bukti transaksi masih belum tersimpan rapi, ada beberapa transaksi yang buktinya sudah rusak atau bahkan tidak memiliki bukti transaksi. Hal ini juga menjadi salah satu penghambat dalam penyusunan laporan keuangan.

\section{Diskusi}

Walaupun masih banyak kelemahan yang dimiliki oleh mitra koperasi kamu, namun hasil kegiatan pengabdian kami memberikan beberapa dampak bagi koperasi bromo semeru center Kecamatan Tumpang, yaitu (1) Peningkatan pemahaman mitra koperasi atas pentingnya laporan keuangan. Tim pengabdian telah memberikan pelatihan berbagai materi yang dibutuhkan oleh mitra koperasi. Pemahaman paling penting yang diperoleh mitra adalah pentingnya penyusunan dan penyajian laporan keuangan yang efektif dan efisien. Selain itu, mitra koperasi lebih mamahami tujuan penting dalam menyampaikan laporan keuangan pada kegiatan RAT. Selanjutnya, pengurus koperasi mitra juga memperoleh pengetahuan baru mengenai acuan atau dasar yang digunakan dalam Menyusun laporan keuangan, yaitu SAK ETAP. (2) Peningkatan kerapian dalam penyimpanan bukti transaksi. Melalui kegiatan pendampingan dalam melakukan praktik pencatatan hingga penyusunan laporan keuangan oleh tim pengabdian, mitra dapat lebih memahami perlunya penyimpanan bukti transaksi dengan rapi. Melalui pendampingan ini, mitra memperoleh pengetahuan baru bahwa kerusakan atau kehilangan bukti tranksasi dapat 
menyulitkan pengurus koperasi mitra mencatat jurnal dan buku besar yang diperlukan. Oleh karena itu, pengurus koperasi mitra kedepannya akan menyimpan semua bukti transaksi lebih baik. Selain itu, melalui pendampingan ini, pengurus koperasi mitra mengetahui manfaat dari buku besar pembantu, khususnya buku besar pembantu piutang. Melalui buku besar pembantu ini, pengurus mitra koperasi menjadi terbantu dalam mengontrol piutang setiap anggotanya. (3) Peningkatan keterampilan dalam melakukan pencatatan dan penyusunan laporan keuangan sederhana. Selebihnya, melalui kegiatan pendampingan ini, pegurus koperasi mitra juga mampu meningkatkan keterampilannya dalam akuntansi. Pada awalnya pengurus koperasi mitra tidak memiliki pengetahuan tentang alur akuntansi, namun dengan adanya pendampingan ini mitra menjadi memahami alur-alur yang harus dilakukan dalam sistem akuntansi koperasi. Walaupun masih dengan cara sangat sederhana, pengurus koperasi mulai memiliki keterampilan dalam membuat jurnal setiap transaksi, mencatat dalam buku besar dan buku pembantu, membuat neraca lajur, hingga menyusun laporan keuangan. Laporan keuangan yang mampu disusun oleh pengurus koperasi masih sangat sederhana, yaitu laporan neraca, laporan laba rugi, dan laporan perubahan modal. Meskipun masih sederhana, namun pengurus koperasi mitra merasa bahwa ketiga laporan keuangan ini mampu mengcover dari transaksi-transaksi yang terjadi dalam operasional koperasi.

\section{Kesimpulan}

Berdasarkan kegiatan yang dilakukan bersama dengan mitra dapat disimpulkan beberapa hal. Pertama, pengurus koperasi mitra dapat meningkatkan pemahaman mengenai laporan keuangan dan pentingnya penyampaian laporan keuangan pada kegiatan RAT. Kedua, terciptanya sistem akuntansi sederhana dalam koperasi mitra melalui Microsoft excel. Ketiga, pengurus koperasi mitra dapat meningkatkan ketrampilan dalam bidang akuntansi, khususnya yang diperlukan dalam operasional koperasi sehari-hari. Selain itu, kami memberikan beberapa saran untuk mitra. Pertama, ada baiknya apabila pengurus koperasi mitra selalu mengupgrade pengetahuan dalam bidang akuntansi, mengingat sering terjadinya perubahan standar akuntansi. Kedua, koperasi diharapkan dapat selalu aktif mengadakan kegiatan RAT setiap tahun, dengan salah satu agendanya adalah penyampaian laporan keuangan kepada anggota. Dengan kegiatan RAT yang rutin dilakukan,diharapkan sanksi menonaktifkan koperasi tidak terulang lagi.

\section{Pengakuan/Acknowledgements}

Terima kasih kami ucapkan kepada Ketua, pengurus, dan anggota Koperasi Bromo Semeru Center Kecamatan Tumpang yang telah mensukseskan pelatihan pelaporan keuangan guna persiapan rapat anggota tahunan (RAT). 


\section{Daftar Referensi}

Agustia, D., \& Palupi, A. (2016). Praktik Creative Accounting Pada Koperasi Di Jawa Timur. EKUITAS (Jurnal Ekonomi Dan Keuangan), 20 (4), 528. https://doi.org/10.24034/j25485024.y2016.v20.i4.1996

Aulia, T. Z., \& Hamdani. (2018). Pemahaman atas Laporan Keuangan Guna Ketepatan Waktu Pelaksanaan Rapat Anggota Tahunan (RAT) pada Koperasi di Kota Tangerang. Prosiding Seminar Nasional Unimus, 1, 453-460.

Depkop. (2019). Laporan Data Koperasi. http://www.depkop.go.id/uploads/laporan/ 1580298872_Data Koperasi 31 Desember 2019-1.pdf

Hamdani, \& Aulia, T. Z. (2018). Persepsi Pengurus Koperasi Terhadap Ketepatan Waktu Rapat Anggota Tahunan Pada Koperasi Di Kota Tangerang. Jurnal Banyumas, 2007, 808-818.

Hidayat, S. O., Setiana, E., \& Situmeang, C. (2016). Pengembangan Sistem Dan Penguatan Manajemen Koperasi. Jurnal Pengabdian Kepada Masyarakat, 22(4), 26-33.

Permen No. 19 Tentang Penyelenggaran Rapat Anggota Koperasi, 21 (2015).

Purwanti, M., \& Kurniawan, A. (2013). Meningkatkan Kualitas Laporan Keuangan Koperasi Melalui Penerapan Sistem Akuntansi dan Kompetensi (Studi Pada Koperasi di Kota Bandung). STAR-Study \& Accounting Reseach, X(3), 1-12.

Suwetty, M. K. (2017). Pengaruh implementasi nilai, prinsip dan kepemimpinan koperasi terhadap kualitas rapat anggota tahunan. Coopetition, 8(2), 85-98.

Government Regulation No. 20/2008, UU No. 20 Tahun 20081 (2008).

UU RI Nomor 17, Pub. L. No. 17, 1 (2012). https://doi.org/10.1007/s11837-012-03781

Winarko, S. P. (2011). Pengaruh Modal Sendiri, Jumlah Anggota Dan Aset Terhadap Sisa Hasil Usaha Pada Koperasi di Kota Kediri. Nusantara of Research, 01(02), 151-167.

Zulkifli, Z., \& Rachim, R. (2019). Tinjauan Pelaksanaan Rapat Anggota Tahunan (Rat) Pada Koperasi Di Kalimantan Timur Tahun 2017. Jurnal Ekonomika: Manajemen, Akuntansi, Dan Perbankan Syari'ah, 8(2), 12. https://doi.org/10.24903/je.v8i2.759 